\title{
DENDROCHRONOLOGICAL POTENTIAL AND PRODUCTIVITY OF TROPICAL TREE SPECIES IN WESTERN KENYA
}

\author{
ERIC T. DAVID ${ }^{1}$, SOPHAN CHHIN ${ }^{1 *}$, and DAVID SKOLE ${ }^{2}$ \\ ${ }^{1}$ Department of Forestry, Michigan State University, Natural Resources Building, 480 Wilson Road, Room 126, East \\ Lansing, MI 48824-1222, USA \\ ${ }^{2}$ Department of Forestry, Michigan State University, Global Observatory of Ecosystem Services (GOES), 101 Manly Miles \\ Building, 1405 S. Harrison Rd., East Lansing, MI 48823, USA
}

\begin{abstract}
This study focuses on tropical tree growth rates in Western Kenya. The dendrochronological potential of each study species was determined by visual examination of rings, and then cumulative growth trajectories for diameter were synthesized for species of sufficient sample size $(\mathrm{n} \geq 3)$, based on ring-width chronologies. The 14 tree species considered were: Acacia mearnsii, Bridelia micrantha, Combretum molle, Croton macrostachyus, Cupressus lustianica, Eucalyptus camaldulensis, Eucalyptus grandis, Eucalyptus saligna, Grevillea robusta, Mangifera indica, Markhamia lutea, Persia Americana, Syzygium cumini, and Trilepisium madagascariensis. The species with the highest dendrochronological potential included Acacia mearnsii, Cupressus lusitanica, the Eucalyptus spp. and Mangifera indica, which are all non-native species that successfully crossdated. The results also indicated that the species with highest dendrochronological potential had strong radial growth synchrony, which was reflected in high inter-tree correlation and (or) high growth variance explained by the first principal component axis. Furthermore, A. mearnsii and E. camaldulensis were sensitive to annual precipitation and moisture index. The species with the lowest dendrochronological potential were Grevillea robusta and Markhamia lutea. In terms of productivity, the three fastest growing species in the study, based on annual diameter increment, were Eucalyptus camaldulensis, Eucalyptus grandis, and Acacia mearnsii. This study also has great potential to extrapolate historical patterns of diameter growth to understanding annual aboveground biomass and carbon dynamics in Western Kenya.
\end{abstract}

Keywords: dendrochronology, Kenya, productivity, tropical ecosystems.

\section{INTRODUCTION}

Many tropical ecosystems are expected to heavily contribute to the future of climate change and carbon dynamics (IPCC 2007; IPCC 2008). As many tropical ecosystems exist in Africa, the continent has become an area of increasing interest for forestry-related studies. Kenyan ecosystems in particular range in form from dry savannah forests of the north to afro-alpine vegetation in the mountain ranges, tropical rainforests, and mangrove forests near the eastern coast (Maundu and Tegnas 2005). The region of western Kenya, along the River Yala Basin, is home to a mosaic of farmland consisting of

\footnotetext{
*Corresponding author: chhin@msu.edu; Fax: (517) 4321143; Telephone: (517) 353-7251
}

varying degrees of tree cover (Dietz and Kuyah 2011). Because $87 \%$ of this agricultural land contains at least $10 \%$ tree cover, it becomes a significant contributor to stabilizing and possibly increasing carbon sequestration (Zomer et al. 2009).

Dendrochronology has been used in a variety of tropical ecosystems, including Kenya, to create individual species growth models and examine the impact of climate factors (i.e. precipitation) (Stahle 1999; Tarhule and Hughes 2002; Worbes 2002). The formation of periodic tree rings is the key component in linking species growth characteristics with climate seasonality characteristics of the region. However, detection of tree rings in tropical species has proven to be more difficult and the trigger for formation different than that 
of temperate and boreal regions. Dormancy in temperate and boreal tree species is induced by cold temperature during the winter months of the year, producing a distinct ring boundary. Dormancy in tropical species is induced by either a seasonally dry period or an extended duration of flooding in floodplain forests. In either case, cambial dormancy and ring formation in tropical trees is directly controlled by seasonal fluctuations in moisture availability (Rozendaal and Zuidema 2011; Fichtler and Worbes 2012). Although dendrochronology shows good potential for understanding growth-climate relationships in the tropics, standard dendrochronological techniques have not always proven to be effective (Worbes 1995). Tree-ring anomalies such as false or wedging rings, caused by within-season climate fluctuations, have hampered research in these regions (Worbes 2002). Consequently, tree-ring studies in Africa (e.g. Stahle 1999; Stahle et al. 1999; Worbes and Junk 1999; Worbes et al. 2003; Courelet et al. 2005; Therrell et al. 2007; Gebrekirstos et al. 2008; Trouet et al. 2010; Gebrekirstos et al. 2011; Krepkowski et al. 2011; Wils et al. 2011; Mbow et al. 2013), and more specifically Kenya (Martin and Moss 1997; Verheyden et al. 2005; Maingi 2006), are rare.

This paper assessed the dendrochronological potential of individual tree species growing in the Yala River Basin in Western Kenya and then determined annual diameter growth rates of species with a sufficient sample size. The species included in the study are four species that are native to Kenya (Bridelia micrantha, Combretum molle, Croton macrostachyus, and Markhamia lutea) and 10 species that are non-native (Acacia mearnsii, Cupressus lusitanica, Eucalyptus camaldulensis, Eucalyptus grandis, Eucalyptus saligna, Grevillea robusta, Mangifera indica, Persea americana, Syzygium cuminii and Trilepisium madagascariensis).

\section{METHODS}

\section{Study Area}

This study was conducted on three $100 \mathrm{~km}^{2}$ $(10 \times 10 \mathrm{~km})$ blocks of land located in the Yala River Basin of Western Kenya (Figure 1). These three designated areas were labeled as the lower, middle and upper Yala regions with the lower Yala region starting near Lake Victoria. The Yala River catchment, covering an area of $3351 \mathrm{~km}^{2}$, drains into the Winam Gulf in Lake Victoria. The elevation, beginning in the lower Yala region, ranges from $1200 \mathrm{~m}$ to $2200 \mathrm{~m}$ above sea level in the upper Yala region. The lower, middle, and upper Yala regions of this basin receive total annual rainfall of $1874 \mathrm{~mm}, 1977 \mathrm{~mm}$, and $1043 \mathrm{~mm}$, respectively, which follows a slightly bimodal distribution. The source of the bimodal rainfall distribution pattern is the intertropical convergence zone (ITCZ) (Shorrock 2007). The ITCZ shifts throughout the year, resulting in dry and wet periods. In Kenya and the Yala region, the long rainy season generally occurs in March through May and the short rainy season in October-November (Mfundisi 2005; Maingi 2006). A bimodal rainfall pattern creates the potential for some trees to form two ring boundaries in the same calendar year: based on the premise that the dry season induces cambial dormancy, one ring boundary could potentially be formed during the December-February dry season and another boundary during the June-September dry season. There is a decrease in temperature with increasing elevation (i.e. environmental lapse rate) across the Yala regions such that mean annual temperature is $23.4^{\circ} \mathrm{C}$ for lower Yala, $20.8^{\circ} \mathrm{C}$ for middle Yala, and $17.2^{\circ} \mathrm{C}$ for upper Yala.

Climate data were obtained from the Kenya Meteorological Department in Nairobi, Kenya (Kenya Meteorological Department, http://www. meteo.go.ke/). The types of data included minimum and maximum monthly temperature and total monthly precipitation. The primary climate stations from which data were used included the Kisumu Meterological Station (ID\#9034025; $0^{\circ} 6^{\prime} \mathrm{S}, 34^{\circ} 45^{\prime} \mathrm{E}$ ) and Yala Tree Nursery (ID\# 8934189; $0^{\circ} 8^{\prime} \mathrm{N}, 34^{\circ} 32^{\prime} \mathrm{E}$ ) for the Lower Yala, the Kakamega Meteorological Station (ID\#8934096; $\left.0^{\circ} 16^{\prime} \mathrm{N}, 34^{\circ} 45^{\prime} \mathrm{E}\right)$ and Kaimosi Farmer's Training Center (ID\#8934078; $0^{\circ} 13^{\prime} \mathrm{N}, 34^{\circ} 57^{\prime} \mathrm{E}$ ) for the Middle Yala, and the Kakamega Meteorological Station (ID\#8934096; $0^{\circ} 16^{\prime} \mathrm{N}, \quad 34^{\circ} 45^{\prime} \mathrm{E}$ ) and Eldoret Meteorological Station (ID\#8935181; $\left.0^{\circ} 32^{\prime} \mathrm{N}, 35^{\circ} 17^{\prime} \mathrm{E}\right)$ for the Upper Yala. Climate moisture indices (CMI's) were calculated by 


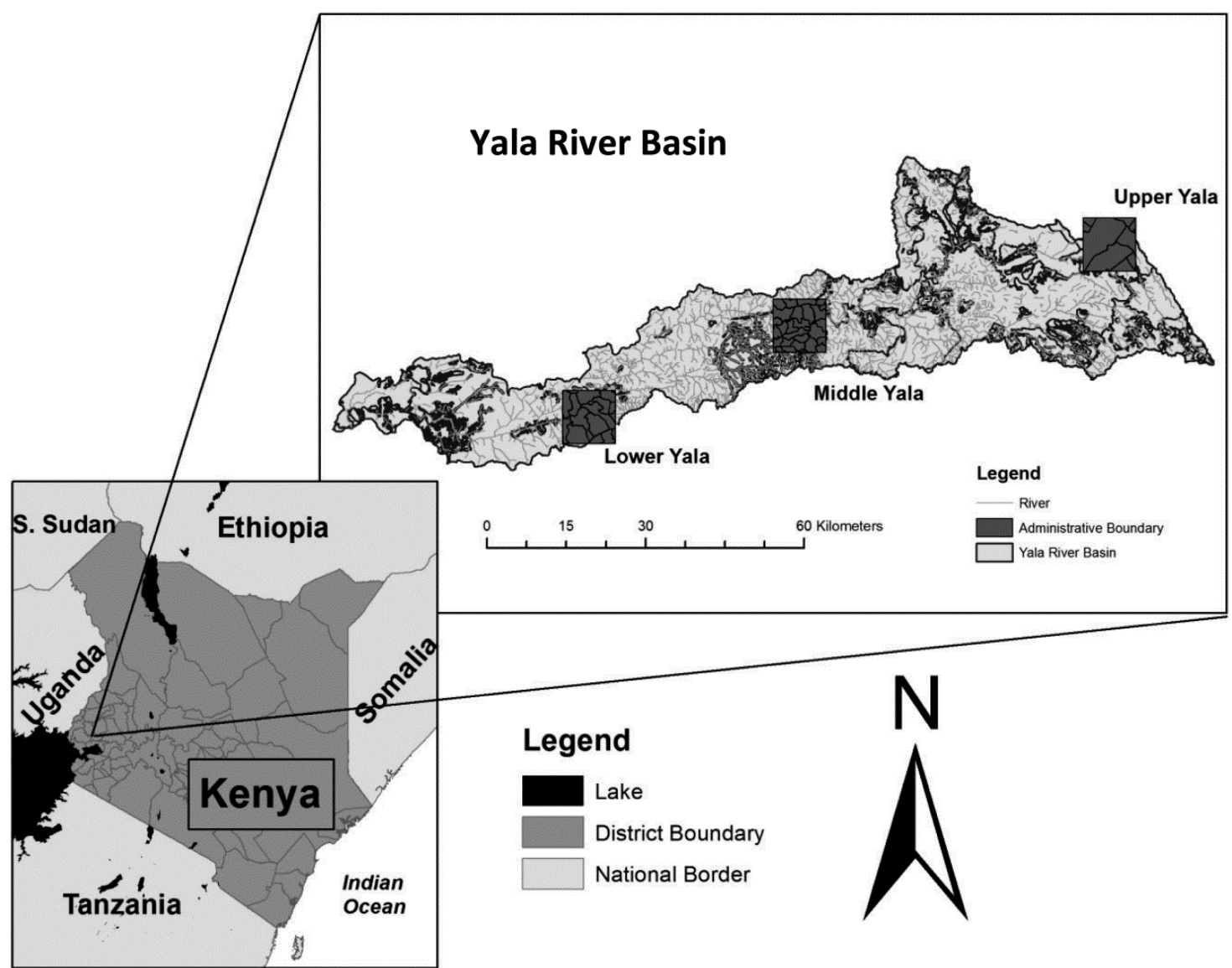

Figure 1. Small map shows the location of Yala River Basin in Western Kenya with neighboring countries in East Africa indicated. Enlarged map (with scale and separate legend) shows the location of three sampling blocks (i.e. lower Yala, middle Yala, and upper Yala represented square dark grey regions) in Yala River Basin of Western Kenya.

subtracting monthly values of potential evapotranspiration (PET) from monthly precipitation (P) values. PET values were determined as a function of minimum and maximum temperature (Hogg 1997). CMI values less than 0 indicate a moisture deficit. Climate data diagrams of monthly precipitation, monthly temperature, and monthly CMI were developed for the lower Yala for the period of 1962-2009, the middle Yala from 19792009, and the upper Yala from 1972-2009 (Figure 2, Figure 3). For each of these three regions, precipitation and CMI were lowest in the dry season months of December, January, and February.

There are several major soil types present along the Yala Basin, including: acrisols, ferralsols and nitrosols (Jaetzold and Schmidt 1982). These soil types exhibit the characteristics of good physical structure, are well drained, deep to very deep and of variable fertility. The variety of soil and climatic conditions along the altitudinal gradient of the basin in conjunction with a highly heterogeneous landscape, which includes a mosaic of farmland, differing degrees of forest cover and open area, has led to a contrast in the dominant tree species found in each region. These species are Markhamia lutea, Eucalyptus spp. and Acacia mearnsii in the lower, middle and upper Yala regions, respectively (Dietz and Kuyah 2011).

\section{Field Sampling}

Each block (lower Yala block, middle Yala block, and upper Yala block) was randomly 

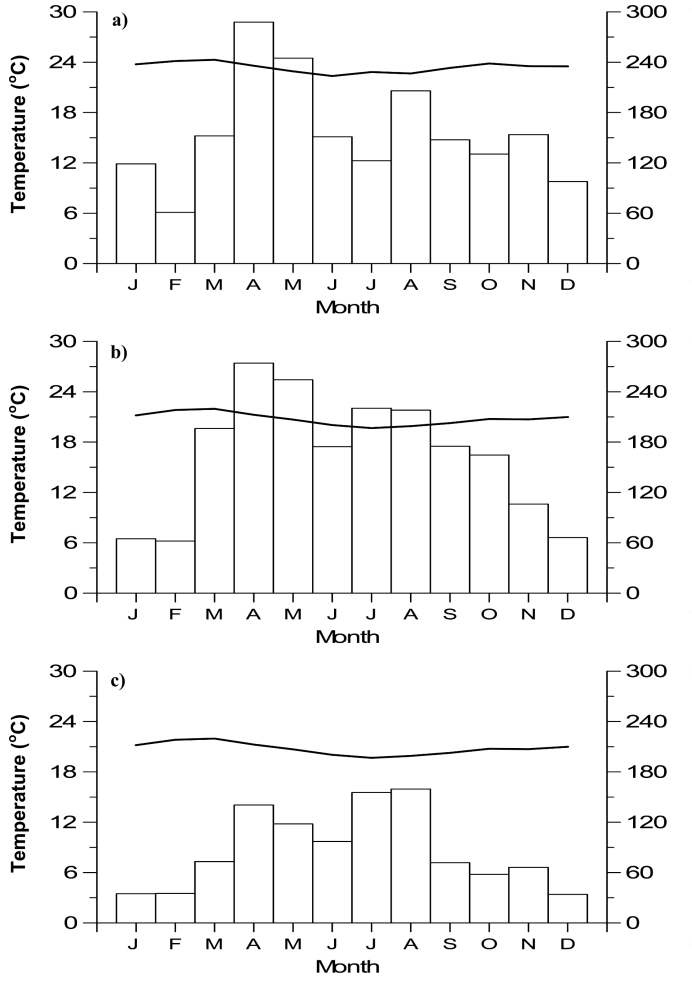

Figure 2. Temperature and precipitation diagrams for the (a) lower Yala block, (b) middle Yala block, and (c) upper Yala block. Average monthly temperature $\left({ }^{\circ} \mathrm{C}\right)$ is represented by a solid line, and total monthly precipitation $(\mathrm{mm})$ is represented by vertical bars.

assigned 160 sample points, which were then randomly sub-sampled $(15 \%$ of the points in lower block, $30 \%$ of the points in the middle block, and $15 \%$ of the points in the upper block). On each of the sub-sample points, a $30 \times 30 \mathrm{~m}$ sampling plot was established and all trees within that plot with a diameter at breast height (DBH) greater than $2.5 \mathrm{~cm}$ were inventoried for $\mathrm{DBH}$. The inventoried trees were subsequently stratified into the following six diameter size classes: $2.5-10$; $10.1-20 ; 20.1-30 ; 30.1-40 ; 40.1-60$ and $>60 \mathrm{~cm}$. In each diameter class, 12 trees (i.e. comprised of 3 trees each from the lower and upper sampling block; and 6 trees from the middle block) were randomly selected for destructive sampling, giving a total of 72 sampled trees (Dietz and Kuyah 2011; Kuyah et al. 2012). This sampling design ensured that a representative mix of tree species and size ranges were sampled in the study area. Given the
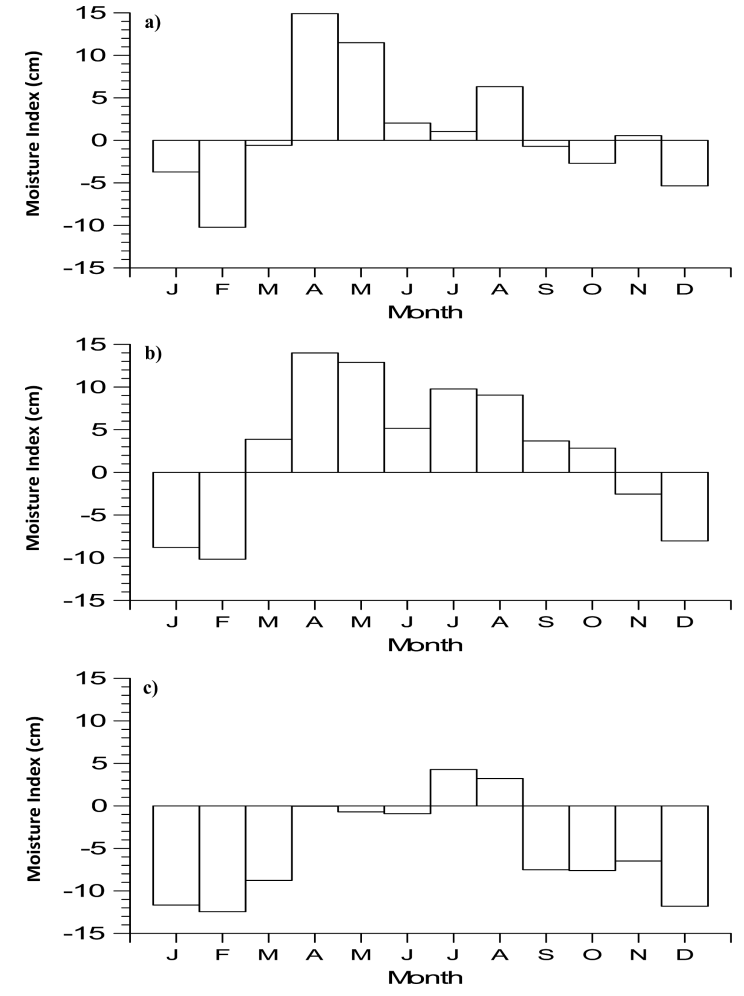

Figure 3. Climate Moisture Index (CMI) diagrams for the (a) Lower Yala, (b) Middle Yala, and (c) Upper Yala blocks.

random sampling procedure used in this study, the species sampled in this study and their level of replication is indicative of how prevalent they are in the Yala regional landscape. The objective of the sampling framework was to sample trees that are proportionally representative of the treed landscape of Western Kenya.

Of the trees chosen for destructive sampling, a stem disc was taken at breast height $(1.3 \mathrm{~m})$. If the disc was between 30 and $60 \mathrm{~cm}$ in diameter, only a half stem disc that included the pith was kept. If the disc was $>60 \mathrm{~cm}$, only a quarter stem disc, which included the pith was kept. These discs were later used for dendrochronological analysis. Sub-sampling large discs was deemed necessary to limit international shipping charges from Kenya to the United States where the dendrochronological analysis took place. The number of half- and quarter-sections was minimal and only represented $19.1 \%$ and $5.9 \%$ of the total number of crosssections, respectively. 
A subset of 68 of the 72 trees were shipped to the United States for dendrochronological analysis and included 14 tropical tree species: $A$. mearnsii, B. micrantha, C. molle, C. macrostachyus, C. lusitanica, E. camaldulensis, E. grandis, $E$. saligna, G. robusta, M. indica, M. lutea, $P$. americana, $S$. cuminii, and T. madagascariensis (Table 2). To limit international shipping charges and because of a sufficient sample size, some large and heavy samples of $E$. camuldensis were not shipped. In addition, each of the following species fell into one of the general shade tolerance categories: tolerant, moderately tolerant, and intolerant. The tolerant species included B. micrantha, C. macrostachyus, and $P$. americana. The moderately tolerant species included $A$. mearnsii, C. molle, and C. lusitanica. Lastly, the intolerant species included the Eucalyptus spp., M. indica, and S. cuminii (World Agroforesry Centre 2012). Information on the shade tolerance of G. robusta, M. lutea, and T. madagascariensis is unavailable.

\section{Laboratory Analysis}

Wood samples were first sanded with progressively finer grits of sandpaper (up to 1200 grit). The dendrochronological potential was then determined for each sample based on the rating system developed by Tarhule and Hughes (2002). Tarhule and Hughes (2002) assigned species to three categories in terms of their usefulness: (1) potentially useful, (2) problematic, and (3) poor. Each species was placed into one of these categories based on the following criteria: (1) distinctiveness of annual ring boundaries, (2) ability to be crossdated, (3) ring circuit uniformity, (4) ring wedging, and (5) ring width variability (sensitivity). This study also utilized this rating system as a way of determining dendrochronological potential. Results of all samples within each species were averaged to obtain an overall species usefulness. The final ratings given were: (1) useful, (2) problematic, or (3) poor.

Each sample with a full cross-sectional disc was visually crossdated along four radii under a binocular microscope to identify missing and/or false rings using the list-method of crossdating to examine temporal synchrony of shared narrow rings (Yamaguchi 1991). Half- and quarter-section sample discs were crossdated along three and two radii, respectively. During this process it was determined whether each species produced a single annual growth ring or a sub-annual ring, based on the visual pattern of the ring widths. Each ring boundary was verified circumferentially between the other available radii of the disc. Trees were then crossdated among different trees within each sampled plot. Results were then summarized across plots within each region. The number of successfully crossdated samples for each species is shown in Table 1.

Seven species (Acacia mearnsii, Cupressus lusitanica, Eucalyptus camaldulensis, Eucalyptus grandis, Eucalyptus saligna, Mangifera indica and Markhamia lutea) were selected as good candidates with a great enough sample size (i.e. three or more trees) for further detailed analysis (Therrell et al. 2007). Annual or sub-annual (for trees with biomodal growth rings) ring widths were measured using a stage micrometer coupled with a binocular microscope to the nearest $0.001 \mathrm{~mm}$ (Velmex: Bloomfield, New York). Disc samples were measured along all radii of each disc that was successfully crossdated from the outmost growth ring inward toward the pith. Of the species analyzed, only sufficient samples from the same block (lower Yala, middle Yala, upper Yala) were included. For instance, in the case of M. lutea, four samples were from the middle Yala block and one sample was from the lower Yala block, yet only the four samples from the middle Yala block were used for the subsequent analysis.

\section{Growth Rate Measurements}

For cross-sectional discs in which fewer than four radii were successfully crossdated, a data correction procedure was applied to the ring width measurements in order to prevent over- or underestimation of tree diameter estimates derived from ring width measurements (Gebrekirstos et al. 2008):

$$
\text { Correction Factor }=\mathrm{D}_{\mathrm{IB}, \mathrm{R}} / \mathrm{D}_{\mathrm{IB}, \mathrm{A}}
$$

where $\mathrm{D}_{\mathrm{IB}, \mathrm{A}}$ is the actual diameter inside bark of the cross-sectional disc determined with a measurement 


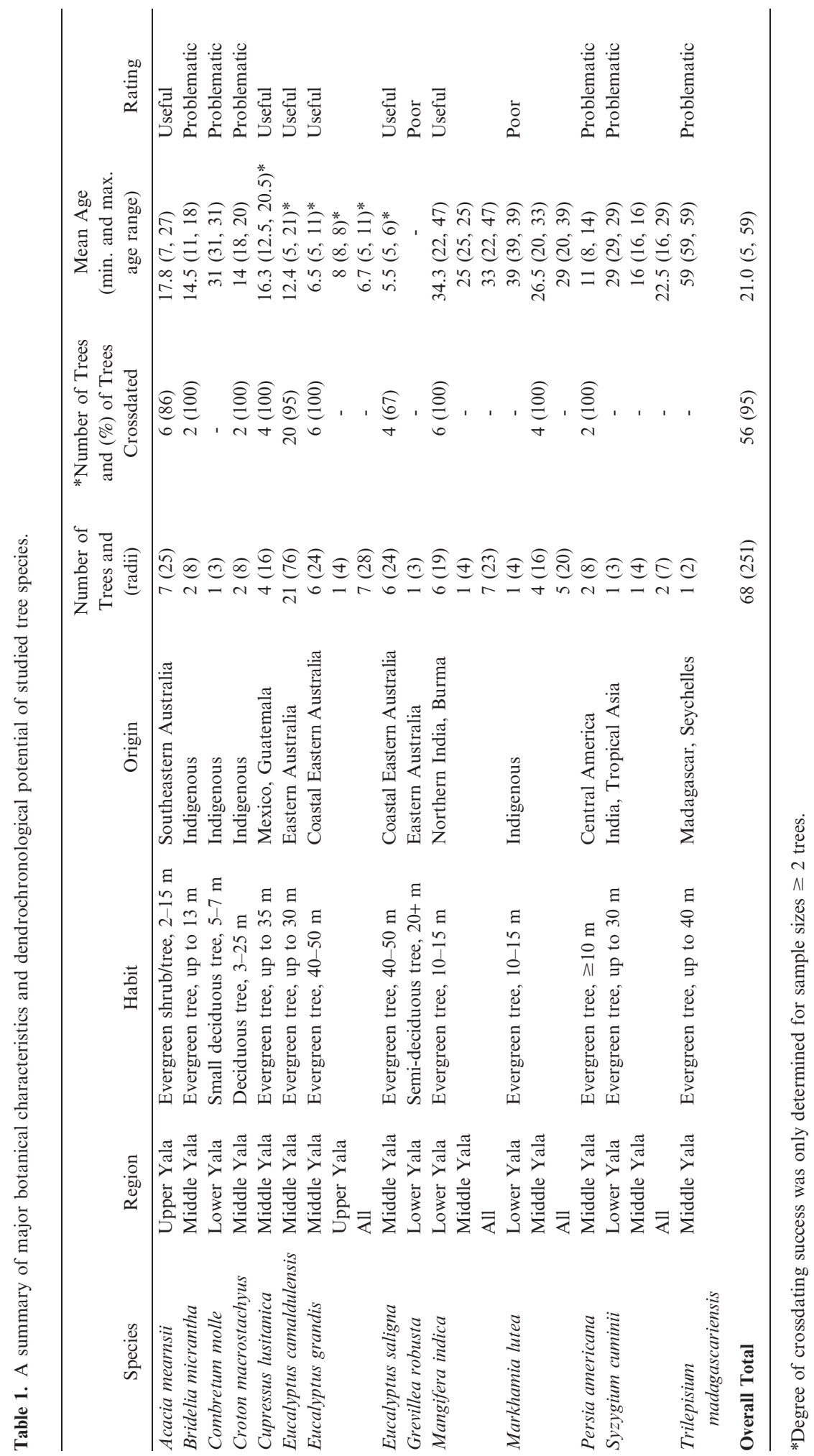


Table 2. Descriptive statistics of mean annual diameter increment summarized by tree species for which sample replication was $\mathrm{n} \geq 3$ trees.

\begin{tabular}{|c|c|c|c|c|c|}
\hline \multirow[b]{3}{*}{ Species } & \multirow[b]{3}{*}{ Region } & \multirow[b]{3}{*}{ Growing Season } & \multirow[b]{3}{*}{ Mean End Age } & \multicolumn{2}{|c|}{ Diameter } \\
\hline & & & & $\begin{array}{l}\text { Age Period: } \\
\text { 1-End* }\end{array}$ & $\begin{array}{c}\text { Age Period: } \\
1-10^{* *}\end{array}$ \\
\hline & & & & Mean $(\mathrm{cm})(\mathrm{n})$ & Mean $(\mathrm{cm})(\mathrm{n})$ \\
\hline Acacia mearnsii & Upper Yala & Unimodal & 17.8 & $1.60(6)$ & $1.29(5)$ \\
\hline \multirow[t]{3}{*}{ Cupressus lusitanica } & Middle Yala & Long Rainy & 16.3 & $1.24(4)$ & $0.84(4)$ \\
\hline & & Short Rainy & & 0.19 (4) & $0.13(4)$ \\
\hline & & Combined & & $1.43(4)$ & $0.97(4)$ \\
\hline \multirow[t]{3}{*}{ Eucalyptus camaldulensis } & Middle Yala & Long Rainy & 12.4 & $1.40(19)$ & $1.55(15)$ \\
\hline & & Short Rainy & & $0.44(19)$ & $0.48(14)$ \\
\hline & & Combined & & $1.88(19)$ & $2.03(14)$ \\
\hline \multirow[t]{3}{*}{ Eucalyptus grandis } & Middle Yala & Long Rainy & 6.5 & $1.31(6)$ & - \\
\hline & & Short Rainy & & $0.29(6)$ & - \\
\hline & & Combined & & $1.60(6)$ & - \\
\hline \multirow[t]{3}{*}{ Eucalyptus saligna } & Middle Yala & Long Rainy & 5.5 & $1.08(4)$ & - \\
\hline & & Short Rainy & & $0.29(4)$ & - \\
\hline & & Combined & & $1.37(4)$ & - \\
\hline Mangifera indica & Lower Yala & Unimodal & 34.3 & $1.01(6)$ & $0.68(6)$ \\
\hline Markhamia lutea & Middle Yala & Unimodal & 26.5 & $0.60(4)$ & $0.26(4)$ \\
\hline
\end{tabular}

*Age Period: 1-End refers to the time period from age one up to the entire period of averaged growth.

**Age Period: 1-10 refers to the time period from age one up to age 10 of averaged growth.

tape and $\mathrm{D}_{\mathrm{IB}, \mathrm{R}}$ is the maximum diameter inside bark determined from the cumulative ring width measurements. The ring width measurements were all divided by this correction factor. In cases where four radii were successfully crossdated for a disc, this correction factor was not applied. It was assumed that when the measurements of the four radii were averaged, error in diameter estimation would be corrected for. At the end of each growth period, the corrected (or non-corrected) ring width measurements for each radius were converted to cumulative measures of diameter inside bark $\left(\mathrm{D}_{\mathrm{IB}}\right)$.

The bark ratio (BR) was determined using the following equation (Bush and Brand 2008):

$$
\mathrm{BR}=\mathrm{D}_{\mathrm{IB}} / \mathrm{D}_{\mathrm{OB}}
$$

where $\mathrm{D}_{\mathrm{IB}}$ is the diameter inside bark and $\mathrm{D}_{\mathrm{OB}}$ is the diameter outside bark. Cumulative $\mathrm{D}_{\mathrm{OB}}$ values can be obtained by dividing $\mathrm{D}_{\mathrm{IB}}$ by BR. Annual diameter increment $\left(\mathrm{cm} \mathrm{year}^{-1}\right)$ was calculated by subtracting cumulative growth in the previous year (t-1) from the current year (t). Annual stem diameter $\left(\mathrm{cm}\right.$ year $\left.{ }^{-1}\right)$ values calculated for the radii of the same disc were averaged together (Table 2).

\section{Dendroclimatic Analysis}

Annual basal area increment $\left(\mathrm{cm}^{2}\right.$ year $\left.{ }^{-1}\right)$ was calculated by subtracting cumulative growth in the previous year $(\mathrm{t}-1)$ from the current year $(\mathrm{t})$. Essentially, the formula for the area of a circle was used to calculate the current $(\mathrm{t})$ and previous $(\mathrm{t}-1)$ years' area growth and the difference between these two areas is a representation of annual basal area increment. However, even when considering basal area, age-related trends exist and standardization was used to eliminate those trends. Each basal area increment series was detrended using a locally weighted regression with a neighborhood span equivalent to 10 years using the function loess (package STATS) in the program R (the open source version of program $S$ ) (Venables and Ripley 2002; Chhin et al. 2008). Following 

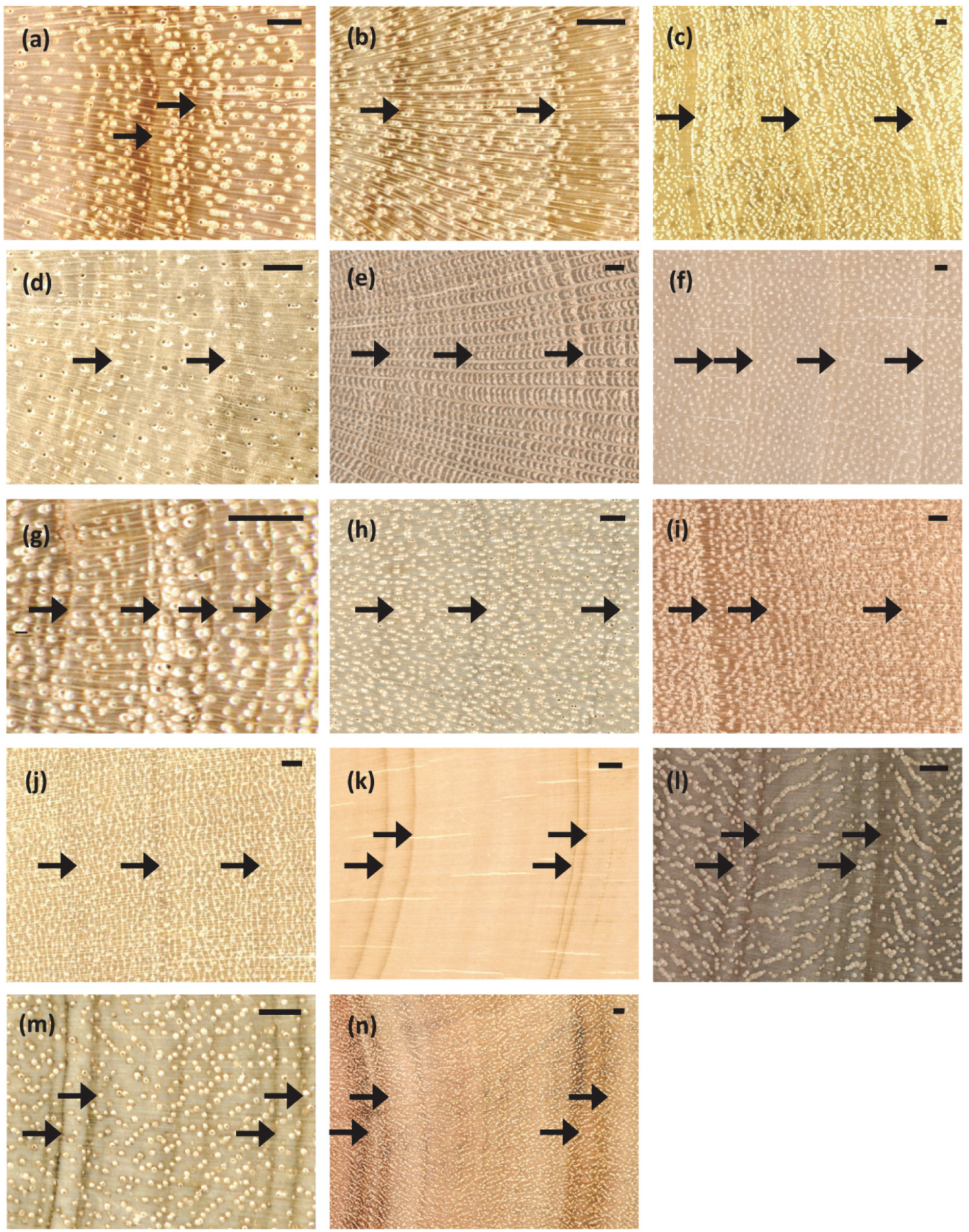

Figure 4. Images of the transverse surface of wood samples of 10 tropical tree species showing annual tree rings produced under a bimodal precipitation regime: Acacia mearnsii (a), Bridelia micrantha (b), Combretum molle (c), Croton macrostachyus (d), Grevillea robusta (e), Mangifera indica (f), Markhamia lutea (g), Persia americana (h), Syzygium cuminii (i) and Trilepisium madagascariensis (j); and four tropical tree species showing bi-annual tree rings produced under a bimodal precipitation regime: Cupressus lusitannica (k), Eucalyptus camaldulensis (1), Eucalyptus grandis (m), and Eucalyptus saligna (n). The boundaries for one year of growth in the 
detrending, indices were standardized by dividing the observed values by the predicted values. Annual standardized stem basal area indices (BAI) calculated for radii of the same disc were averaged together for each tree.

The strength of crossdating at each plot was assessed by calculating inter-tree correlations between all trees in each plot, and then summarized further across plots within each region. For species in which the BAI chronology was greater than or equal to 15 years, inter-tree analysis was conducted using Pearson correlation analysis. For species in which the BAI chronology was shorter than 15 years, inter-tree analysis was run using a nonparametric Spearman rank correlation analysis. First-order autocorrelation was also determined for the BAI chronologies of each tree species. As an additional measure of the degree of common growth variation amongst the growth series of each species, principal component analysis (PCA) was conducted on a covariance matrix (SYSTAT version 10.2, procedure FACTOR) of the BAI chronologies for each of the tree species over the common period shared by all chronologies.

Growth-climate relationships were examined between the average BAI chronology of each tree species and annual climate variables (i.e. mean annual temperature, total annual precipitation, and Climate Moisture Index). For species in which the BAI chronology was greater than or equal to 15 years, dendroclimatic analysis was conducted using Pearson correlation analysis. For species in which the BAI chronology was shorter than 15 years, dendroclimatic analysis was run using non-parametric Spearman rank correlation analysis.

\section{RESULTS}

\section{Dendrochronological Potential}

The assessed dendrochronological potential of all 14 species can be found in Table 1. The majority of the species were found to be at least useful or problematic. The species in the useful category included $A$. mearnsii, $C$. lusitanica, the Eucalyptus spp. and $M$. indica, which are all nonnative to Kenya. These useful species also had the highest inter-tree correlation values (Table 1). Although the ring boundaries of $M$. lutea were demarcated by marginal parenchyma, the species was very troublesome as many instances of ring wedging occurred resulting in a low percentage of radii that were successfully crossdated. The species with the least amount of potential was G. robusta. The ring boundaries of this species were almost indistinguishable.

\section{Tree-Ring Formation Patterns}

The variation in ring boundary distinctiveness among the tropical tree species in Kenya is displayed in Figure 4. Ten tropical tree species showed annual tree rings: A. mearnsii (Figure 4a), B. micrantha (Figure 4b), C. molle (Figure 4c), C. macrostachyus (Figure 4d), G. robusta (Figure 4e), M. indica (Figure 4f), M. lutea (Figure 4g), P. americana (Figure 4h), S. cuminii (Figure 4i) and T. madagascariensis (Figure 4j). In contrast, four tropical tree species showed bi-annual rings and thus growth rings alternated between wide (corresponding to the long rainy season) and narrow widths (corresponding to the short rainy season) within the same annual year: C. lusitanica (Figure 4k), E. camaldulensis (Figure 41), E. grandis (Figure 4m), and E. saligna (Figure 4n). Parenchyma, vessel, and/or fiber characteristics were used to determine the tree-ring boundaries. The wood anatomy descriptions follow those of Bowyer et al. (2007).

Tree-ring boundaries of $A$. mearnsii were discerned by a decrease in vessel diameter and a darker color of the fiber toward the end of the growing season (Figure 4a). Ring boundaries of $B$. micrantha were distinguished primarily by a decrease in vessel diameter size towards the end of the growing season (Figure 4b). Ring boundaries of $C$. molle were accentuated principally by a thin band

unimodal species and for a partial year's growth in the bimodal species are indicated by the tip of the black arrows. The direction of the arrows indicates the direction of growth from the start to the end of a growing season. The scale bar in the top-right corner of each sub-figure is equivalent to a length of $1 \mathrm{~mm}$. 
of marginal parenchyma and also by a decrease in vessel diameter size toward the end of the growing season (Figure 4c). Tree rings of C. macrostachyus were typified by a darker colored fiber at the beginning of the growing season compared to the lighter color at the end, which provided contrast (Figure 4d). Rings of G. robusta had an initial band of parenchyma associated with larger diameter vessels early in the growing season; however, ring boundaries were difficult to detect because it was hard to distinguish between the initial band of parenchyma with the prevalent intrannual banded confluent parenchyma (Figure 4e). Tree-ring boundaries of both $M$. indica (Figure 4f) and $M$. lutea (Figure $4 \mathrm{~g}$ ) were determined by a thin band of marginal parenchyma. Ring boundaries of $M$. lutea were furthermore accentuated by a decrease in vessel diameter size and darker fiber color near the end of the growing season. $P$. americana rings were characterized by a darker color of fiber near the end of the growing season (Figure 4h). S. cuminii rings generally had slightly smaller diameter vessels at the end of the growing season and a thicker band of fiber tissue early in the growing season (Figure 4i). Tree-ring boundaries of $T$. madagascariensis were characterized by alternating bands of fiber tissue and aliform confluent parenchma with the distance between each band decreasing towards the end of the growing season; this growth pattern created the visual effect of a darker fiber color at the beginning of the growing season (Figure 4j).

In terms of the bimodal tropical tree species, C. Iusitanica had a typical gymnosperm wood pattern, with earlywood and latewood (characterized by smaller diameter lumens and thicker cell walls of the tracheids vessels) produced in each of the rainy seasons (Figure 4k). Tree-ring boundaries of all the Eucalyptus spp. (i.e. E. camuldensis, E. grandis, E. saligna) were similar and were characterized by a decrease in vessel diameter size and darker fiber color toward the end of each rainy season (Figures $41, m, n$ ).

\section{Growth Chronologies and Sensitivity of Growth to Annual Climate}

Growth index chronologies were divided into two groups of species. The first group contained

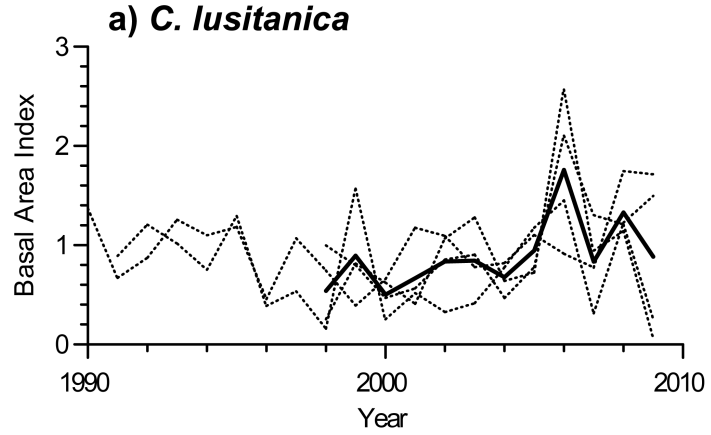

b) E. camaldulensis
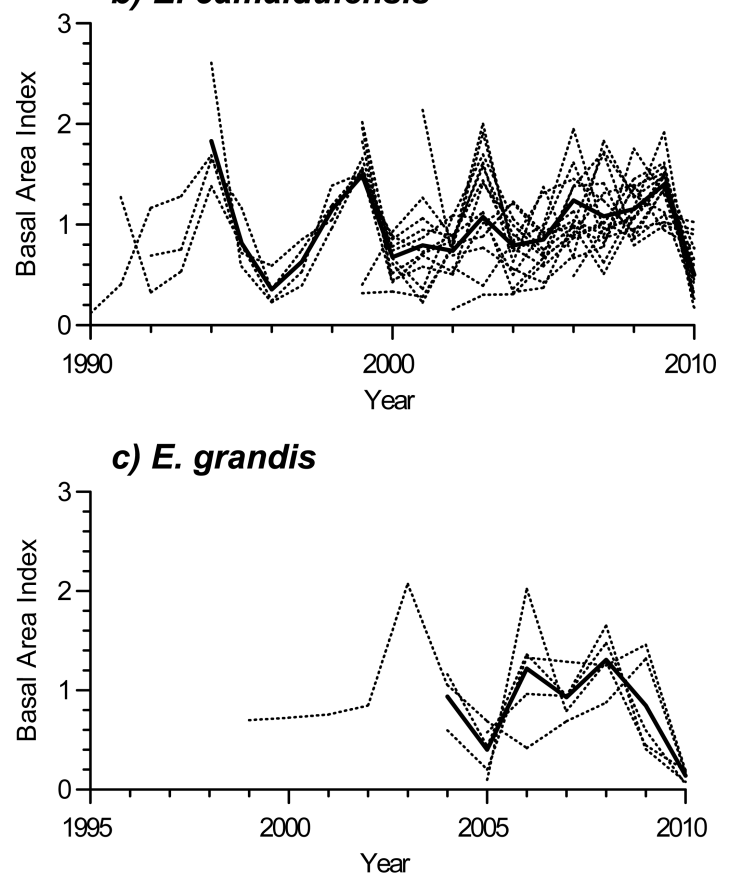

d) E. saligna

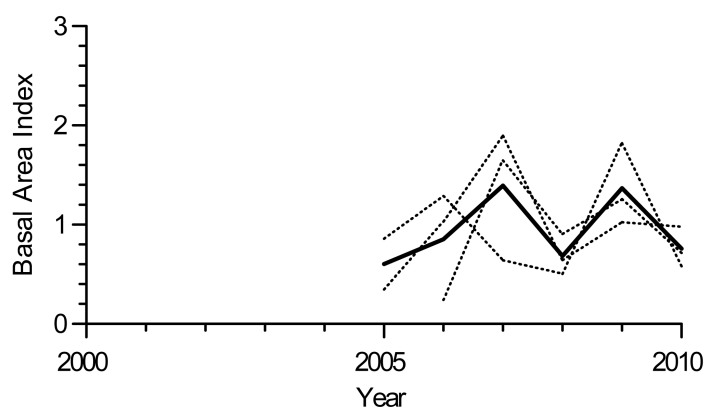

Figure 5. Basal area index (BAI) chronologies summarized by common plantation species. For each species, dashed lines show BAI chronologies for individual trees and bold solid line represents the mean BAI chronology. 
the species most commonly grown in plantations (Figure 5: C. lusitanica, E. camaldulensis, E. grandis, E. saligna), while the second group contained the species commonly found in a natural forest setting (Figure 6: A. mearnsii, $M$. indica, M. lutea).

The strength of inter-tree correlation was statistically significant for $A$. mearnsii and $\mathrm{C}$. lusitanica $(\mathrm{p}<0.05)$ (Table 3). Principal component analysis (PCA) showed that the percentage of the total variance explained by the first principal component (PC1) was greater than that expected under the broken stick null model (Legendre and Legendre 1998) for 6 of the well-replicated species (i.e. A. mearnsii, C. lusitanica, E. camaldulensis, E. grandis, $M$. indica, M. lutea) (Table 3).

Growth of A. mearnsii $(\mathrm{r}=0.48, \mathrm{r}=0.54)$ and $C$. lusitanica $(\mathrm{r}=0.50, \mathrm{r}=0.51)$ was positively correlated with both total annual precipitation and Climate Moisture Index (all p $<0.05$ ) (Table 3). Growth of all species was not significantly related to temperature (all $\mathrm{p} \geq 0.05$ ).

\section{Mean Annual Growth Increments and Cumulative Growth Trajectories}

By calculating annual growth parameters, quick comparisons can be made between the different species based on their rate of productivity (Table 2). The three fastest growing species in the study, based on annual diameter increment, were E. camaldulensis, E. grandis, and A. mearnsii (Table 2).

The cumulative diameter growth trajectory of the plantation species showed all the Eucalyptus spp. growing faster within the first five years than $C$. lusitanica, with $E$. grandis growing slightly faster than the other two Eucalyptus spp. (Figure 7a). Because of the short length of the E. grandis and E. saligna chronologies related to the young age of the plantations, it is impossible to determine their cumulative diameter growth rates beyond 510 years of age. Among the non-plantation species, $A$. mearnsii was clearly the fastest growing species from an early age. $M$. indica, however, surpassed $A$. mearnsii around the age of 25. M. lutea was well below the other two species in cumulative diameter growth (Figure $7 b$ ).
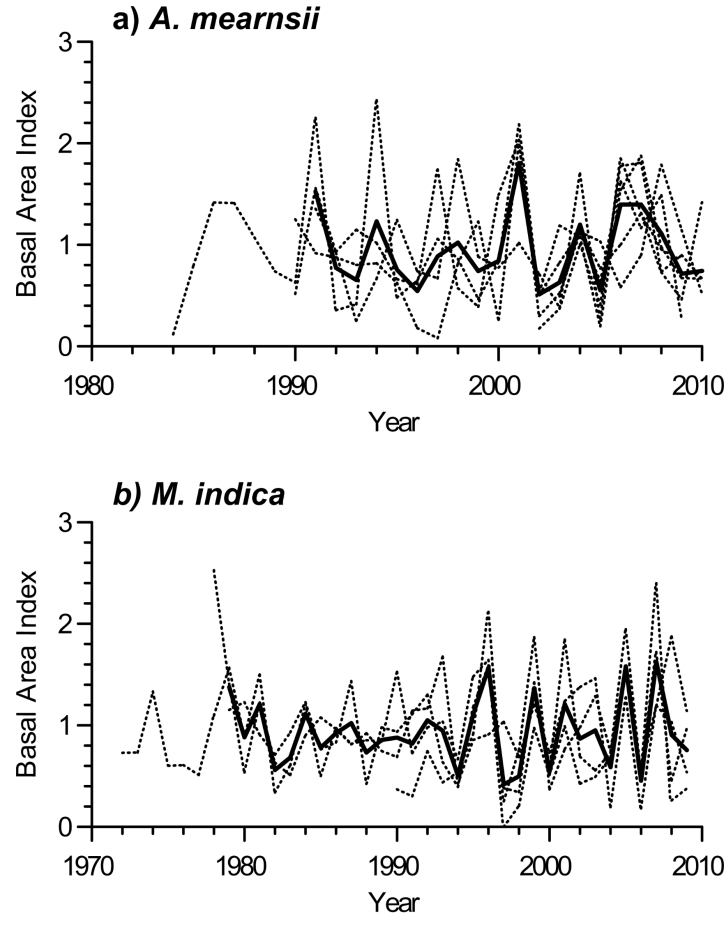

c) M. Iutea

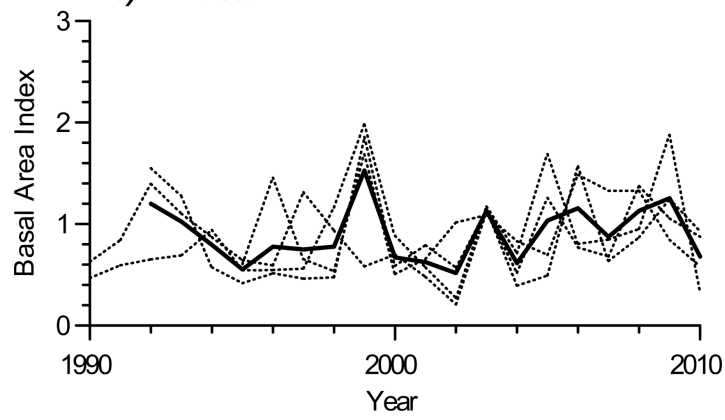

Figure 6. Basal area index (BAI) chronologies summarized by non-plantation species. For each species, dashed lines show BAI chronologies for individual trees and bold solid line represents the mean BAI chronology.

\section{DISCUSSION}

\section{Dendrochronological Potential}

A certain degree of difficulty was present in detecting the growth-ring boundaries of several of the study species. It has been noted that tropical ring boundaries tend to be clearer and more distinct in regions that exhibit a unimodal rainfall distribution (Worbes 1995). The single annual 
Table 3. Statistical properties of basal area index chronologies (inter-tree correlation, first-order auto-correlation, percentage of total variance explained by first principal component) and relationship between basal area index and annual climatic variables (mean annual temperature, total annual precipitation, and annual Climate Moisture Index).

\begin{tabular}{llcccccc}
\hline \multicolumn{1}{c}{ Species } & Region & $\begin{array}{c}\text { Inter-tree } \\
\text { corr. }\end{array}$ & $\begin{array}{c}\text { Auto- } \\
\text { corr. }\end{array}$ & $\begin{array}{c}\text { Variance (\%) in First } \\
\text { Principal Component }\end{array}$ & $\begin{array}{c}\text { Temp. } \\
\text { Precip. }\end{array}$ & $\begin{array}{c}\text { Climate } \\
\text { Moisture Index }\end{array}$ \\
\hline Acacia mearnsii & Upper Yala & $0.61^{*}$ & -0.20 & $66.1^{* *}$ & -0.21 & $0.48^{*}$ & $0.54^{*}$ \\
Cupressus lusitanica & Middle Yala & $0.62^{*}$ & 0.02 & $60.1^{* *}$ & 0.45 & 0.30 & 0.28 \\
Eucalyptus camaldulensis & Middle Yala & 0.45 & 0.04 & $46.6^{* *}$ & -0.25 & $0.50^{*}$ & $0.51^{*}$ \\
Eucalyptus grandis & Middle Yala & 0.53 & -0.13 & $73.4^{* *}$ & -0.64 & 0.43 & 0.43 \\
Eucalyptus saligna & Middle Yala & 0.33 & -0.53 & 55.0 & -0.60 & 0.50 & 0.50 \\
Mangifera indica & Lower Yala & 0.37 & -0.22 & $60.4^{* *}$ & -0.03 & 0.14 & 0.25 \\
Markhamia lutea & Middle Yala & 0.27 & -0.07 & $55.7^{* *}$ & 0.05 & 0.29 & 0.27 \\
\hline
\end{tabular}

*Corrrelation coefficient significant at $\mathrm{p}<0.05$. **Observed growth variance $(\%)$ explained by first principal component axis exceeds expected growth variance from broken stick null model (Legendre and Legendre 1998). Autocorrelation was not statistically significant for any of the species (all $\mathrm{p} \geq 0.05$ )

rainy season allows for a more pronounced dry period in which the ring boundary can be formed. Western Kenya, unlike much of Africa, has a bimodal rainfall distribution, which may contrib-

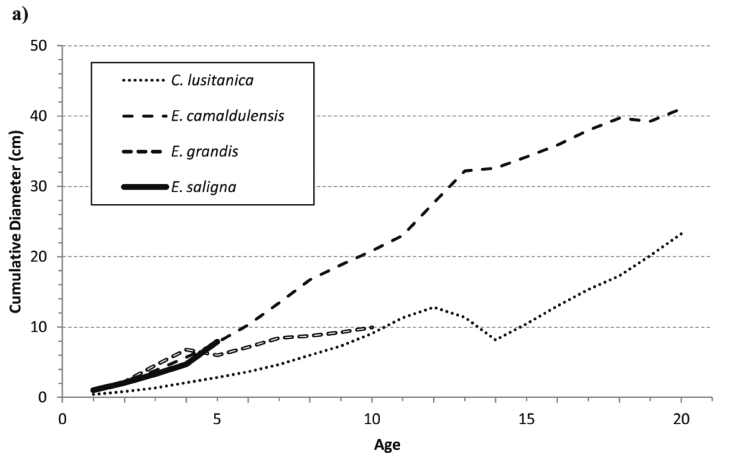

b)

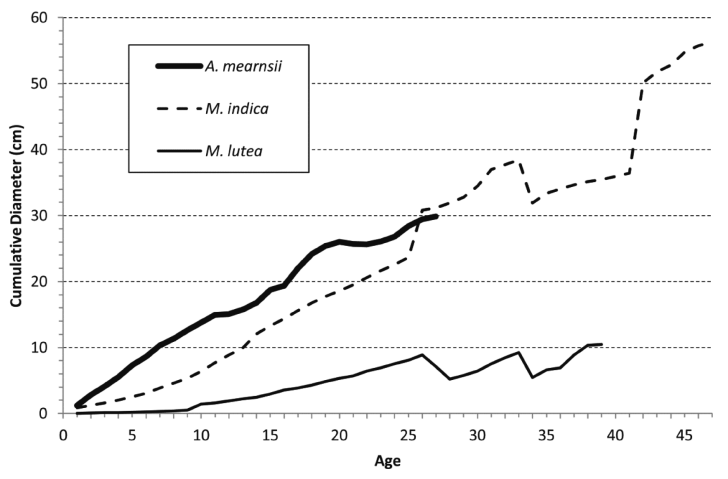

Figure 7. Cumulative patterns in diameter outside bark summarized by common plantation tree species (a) and nonplantation species (b). ute to the reduction in clarity of the ring boundaries. However, even if the region of study experiences a bimodal rain pattern, certain tree species may still only produce one annual ring (Verheyden et al. 2004). In the current study, the potential reason for why many of the studied species displayed a unimodal ring structure is because there is only one pronounced dry season from December to February in each of the three Yala regions (Figure 3). In contrast, C. lusitanica and the three Eucalyptus spp. had a biomodal ring pattern; we speculate that because these species are plantation species and non-indigenous to the region by being far removed from their initial places of origin, the bimodal ring pattern of these species could potentially imply incomplete adaptation to the local climate (Wils et al. 2011).

The most frequent problems related to ringboundary identification were ring wedging, indistinct boundaries, and/or occasionally fire scars. Despite difficulties, several of the species showed a useful potential for dendrochronology. These species include $A$. mearnsii, $M$. indica, C. lusitanica, E. camaldulensis, E. grandis, and E. saligna. In addition, $A$. mearnsii and $C$. lusitanica also showed significantly high inter-tree correlation. Furthermore, A. mearnsii, M. indica, C. lusitanica, $E$. camaldulensis, and $E$. grandis had a significant amount of growth variation explained by their first principal component axis. $M$. indica was the species with the highest dendrochronological potential, likely because it produced a distinct 
band of marginal parenchyma denoting the ring boundary. $M$. indica is a fruit tree grown commonly throughout Kenya (Maundu and Tengnas 2005). Another tree-ring study in Kenya, conducted by Maingi (2006), found that the species with the most distinct ring boundaries were those that produced marginal parenchyma. C. lusitanica and all three Eucalyptus species did not have a distinct line of marginal parenchyma marking the ring boundary, but other characteristics promoted ring-boundary detection. The distinctiveness of the rings of $C$. lusitanica could be explained by its sensitivity to climate, edaphic conditions, and light exposure (Miller and Knowles 1990; Cros et al. 1999; Nicholas 2007; Watt et al. 2009). For instance, in New Zealand, productivity of $C$. lusitanica as measured by site index was shown to be related with mean minimum air temperature and the degree of ground frost in the summer in the high elevation inland sites (Watt et al. 2009). In the state of Rio de Janeiro, Brazil, de Oliveira et al. (2011) were able to successfully identify the tree-ring boundaries of $E$. grandis trees using X-ray densitometry techniques, the same methodology used by Delgado-Matas and Pukkala (2011) in Angola on E. camaldulensis, E. grandis, and E. saligna trees. Of the remaining potentially useful study species, few dendrochronological studies exist in which dendrochronological potential and growth productivity are examined, limiting opportunities for comparison.

The species in this study determined to be either problematic or poor include: B. micrantha, C. molle, C. macrostachyus, G. robusta, M. lutea, $P$. americana, S. cuminii, and T. madagascariensis. The species that displayed the highest frequency of ring wedging was $M$. lutea. Its slow growing nature (Akyeampong et al. 2005), similar to that of an understory tree, may explain the high frequency of ring wedging found in the species (Couralet et al. 2010). Although G. robusta was not successfully crossdated in this study and no growth rates could be determined, Nath et al. (2011) found that $G$. robusta has a relatively fast growth rate in India in comparison to native shade trees based on measurements from steel dendrometer bands. Because we only examined one sample of $G$. robusta, additional sampling is required before a more definitive assessment of its dendrochronological potential can be made. Although several of these species were listed as problematic and displayed varying difficulty of crossdating among samples, they were not completely useless for dendrochronological purposes. Few dendrochronological studies have been conducted on the remaining species in the problematic category and so meaningful comparisons could not be made. It was interesting to note that all of the tree species that were indigenous to Kenya were rated as either problematic (i.e. B. micrantha, C. molle, $C$. macrostachyus) or poor (i.e. M. lutea) in terms of dendrochronological potential. The potential reason for this is that native species growing in their optimal range of ecological amplitude may not be stressed as much by environmental factors and thus may show more complacent growth series that are more difficult to crossdate (Wils et al. 2011).

The samples used in this study were all stem discs. The majority of discs were complete, but a small proportion were either half discs or quarter discs because of the large circumference of the tree and difficulty of transportation. Previous studies (e.g. Maingi 2006) included increment core samples as well, but determined that they were insufficient for accurate ring detection, based on the common occurrence of wedged and/or false rings. True-ring boundaries in tropical trees typically span the entire circumference of the tree (Worbes 2002). Therefore, using full stem discs helps in determining which ring boundaries are real and which are false or missing. Although full stem discs have been proven as a better means for tropical dendrochronology, destructive sampling is required to obtain them (Stahle 1999).

The length of the tree-ring record was generally short for trees considered in this study. In this study and in other tropical dendrochronological studies, species generally show more clearly defined annual rings during their juvenile growth phase but become more difficult to crossdate as they age (Sousa et al. 2012; Mbow et al. 2013). Juvenile trees, with a more poorly developed root system, may not have access to the same water sources as fully developed canopy trees. Furthermore, most juvenile tropical trees grow slowly because of low light availability in the forest understory (Rozendaal and Zuidema 2011). The 
more stressed condition of juvenile trees would promote the likelihood of forming more clearly demarcated rings.

\section{Annual Growth Rates and Cumulative Growth Trajectories}

Growth rates among the well-replicated species in the study varied greatly, with $E$. grandis being the fastest growing species during early years and $M$. lutea being the slowest growing species. Delgado-Matas and Pukkala (2011) successfully determined the growth rates of six Eucalyptus species in Angola through the use of X-ray densitometry, but the mean diameter growths of E. camaldulensis, E. grandis, and E. saligna after five years were $5 \mathrm{~cm}, 4 \mathrm{~cm}$, and $6 \mathrm{~cm}$, respectively, which were all below those of the current study. This discrepancy could be because of the significantly colder temperatures experienced during the winter months in Angola or the lack of thinning in the Angola study site. In a mixed species plantation study in Australia, Forrester et al. (2004) found mean cumulative diameter growth in A. mearnsii to range from 10 to $16 \mathrm{~cm}$ at 11 years of age, with mean cumulative diameter of trees in this study falling within that range at $15 \mathrm{~cm}$. In concurrence with this study, Akyeampong et al. (1995) also found that in the highlands of Burundi, $M$. lutea was a very slow growing species, obtaining a DBH of only $3.1 \mathrm{~cm}$, three and a half years after planting. The diameter growth rates of C. lusitanica in this study are lower than previously reported rates of $14.6 \mathrm{~cm}$ at age 7 by Luoga. (1994) in Tanzania. Because Tanzania exhibits a precipitation pattern much like that of Kenya, other factors (e.g. genetics, soils) may be contributing to the discrepancy in growth rates. Few wood productivity studies have been conducted on $M$. indica, as most studies focus on the fruit and reproductive aspects of the tree.

\section{Sensitivity of Growth to Annual Climate}

Both A. mearnsii and E. camaldulensis were positively correlated with total annual precipitation and Climatic Moisture Index. These results confirm that moisture stress is likely the main limiting factor conditioning radial growth of these species and inducing strong growth synchrony, which is reflected in high inter-tree correlation and (or) high growth variance explained by the first principal component axis. Gebrekirstos et al. (2008) also confirmed drought sensitivity in Acacia species growing in a semi-arid savanna woodland in Ethiopia. Although the other well-replicated species also showed a direct relationship with annual precipitation and moisture index, these relationships were not statistically significant (Table 3); consequently, it is recommended that increasing sample size and sampling older trees would help strengthen future dendroclimatic analyses of these species.

\section{Implications for Forest Biomass and Carbon Inventories}

As a tool, dendrochronology can be used to calculate tree productivity on an annual basis via the reconstruction of past diameter growth rates, which in turn can be inputted into allometric biomass equations that are a function of tree diameter (Mbow et al. 2013). Consequentially, historical patterns of tree biomass could be developed based on the cumulative patterns of diameter presented in this study (Figure 7) using allometric equations devoloped by Dietz and Kuyah (2011). Forest stand development and productivity are usually measured on permanent sample plots that are inventoried on 5- to 10-year intervals and thus generally take long time periods to collect (Metsaranta and Lieffers 2009). Throughout the tropics permanent plots with a long history of measurements are scarce, and considerable time would be required to obtain useful allometric data from newly established plots. This is a serious data limitation for the use of IPCC (2006) Tier 3 allometric equations (i.e. allometric models based on locally developed data and parameters from a forest stand inventory) in tropical landscapes. Thus the use of dendrochronology to develop new allometry or calibrate general allometry, such as IPCC (2006) Tier 1 (i.e. allometric models based upon global IPCC default values and parameters), is a promising approach to overcoming limitations in tropical environments. 
In general, half of a tree's biomass is made up of carbon, which allows for the easy conversion of biomass to carbon mass (Table 2) (IPCC 2006; Lewis et al. 2009). In the past, forest carbon studies have only evaluated the carbon density and the total carbon storage already in existence (Glenday 2006). Further studies of wood quality factors such as tree density will allow for more accurate assessments of tree carbon content. Therefore, dendrochronology studies such as this one can greatly benefit the implementation of carbon markets including REDD (reducing emissions from deforestation and forest degradation); REDD limits deforestation by providing financial incentives to landowners based on carbon stored in a forest (Kaimowitz 2008; CIFOR 2009). Developing countries, with limited resources can utilize allometric equations in combination with dendrochonological analyses in tropical trees to determine historical annual patterns of carbon content within a tree.

\section{CONCLUSIONS}

The findings of this study provide further evidence that tropical trees have dendrochronological value. Although not all of the study species were successfully crossdated, many of them could still be of use in further studies. The problems encountered during this study were very similar to issues brought up by other researchers, but the exploration of novel techniques (e.g. cambial wounding, electronic dendrometers, stable isotopes, wood staining, x-ray densitometry) is making tropical dendrochronological studies more feasible (Wils et al. 2011). Growth rates were successfully determined for all of the well-replicated species and compared relatively well with values reported in previous literature. Future studies should directly assess whether seasonal climatic factors (i.e. precipitation, temperature, moisture index) have affected tree-ring formation of these tropical tree species in Kenya.

\section{ACKNOWLEDGMENTS}

The funding of this for this study was provided by the World Wildlife Fund as part of the Carbon Benefits Project, and Michigan State University AgBioResearch (Project \# MICL06002). We thank M. Magruder, D. Berry, A. Monks, M. Smalligan, S. Kuyah, and E. Magero for valuable assistance in sample and data collection. We also thank the Associate Editor (M. Hughes) and three anonymous reviewers for their constructive comments.

\section{REFERENCES CITED}

Akyeampong, E., L. Hitimana, S. Franzel, and P. C. Munyemana, 1995. The agronomic and economic performance of banana, bean and tree intercropping in the highlands of Burundi: an interim assessment. Agroforestry Systems 31:199-210.

Anonymous, 2012. Plant Resources of Tropical Africa. Wageningen University, The Netherlands, http://www.prota.co.ke/ en/home. Accessed July 12, 2012.

Bowyer, J. L., R. Shmulsky, and J. G. Haygreen, 2007. Forest Products and Wood Science: An Introduction, 5th ed. Blackwell Publishing, Oxford, UK.

Bush, R. R., and G. Brand, 2008. Lake States (LS) Variant Overview: Forest Vegetation Simulator. USDA For. Serv., Forest Management Service Center, Fort Collins, CO.

Chhin, S., E. H. Hogg, V. J. Lieffers, and S. Huang, 2008. Potential effects of climate change on the growth of lodgepole pine across diameter size classes and ecological regions. Forest Ecology and Management 256:1692-1703.

CIFOR, 2009. Simply REDD: CIFOR's Guide to Forests, Climate Change and REDD. Center for International Forestry Research, www.cifor.cgiar.org.

Couralet, C., U. Sass-Klaasen, F. Sterck, T. Bekele, and P. A. Zuidema, 2005. Combining dendrochronology and matrix modeling in demographic studies: an evaluation for Juniperus procera in Ethiopia. Forest Ecology and Management 216: 317-330.

Couralet, C., F. J. Sterck, U. Sass-Klaassen, J. Van Acker, and H. Beeckman, 2010. Species-specific growth responses to climate variations in understory trees of a Central African rain forest. Biotropica 42:503-511.

Cros, D. T. E., M. Ducrey, D. Barthelemy, C. Pichot, R. Giannini, P. Raddi, A. Roques, A. Salesluis, and B. Thibaut, 1999. Cypress: A Practical Handbook. Studio Leonardo, Florence, Italy; $139 \mathrm{pp}$.

de Oliveira, B. R. U., J. V. D. Latorraca, M. Tomazello, R. A. Garcia, and A. M. de Carvalho, 2011. Dendroclimatology correlations of Eucalyptus grandis Hill ex Maiden of Rio Claro, RJ state - Brazil. Ciencia Florestal 21:499-508.

Delgado-Matas, C., and T. Pukkala, 2011. Comparison of the growth of six Eucalyptus species in Angola. International Journal of Forest Research. doi:10.1155/2011/980259.

Dietz, J., and S. Kuyah, 2011. Guidelines for Establishing Regional Allometric Equations for Biomass Estimation through Destructive Sampling. Carbon Benefits Project: Modelling, 
Measurement and Monitoring, World Agroforestry Centre, Nairobi.

Fichtler, E., and M. Worbes, 2012. Wood anatomical variables in tropical trees and their relation to site conditions and individual tree morphology. IAWA Journal 33:119-140.

Forrester, D. I., J. Bauhus, and P. K. Khanna, 2004. Growth dynamics in a mixed-species plantation of Eucalyptus globulus and Acacia mearnsii. Forest Ecology and Management 193:81-95.

Gebrekirstos, A., A. Brauning, M. van Noordwijk, and R. Mitlöhner, 2011. Understanding past, present, and future climate changes from East to West Africa. Agricultural Innovations for Sustainable Development 3:77-86.

Gebrekirstos, A., R. Mitlohner, D. Teketay, and M. Worbes, 2008. Climate-growth relationships of the dominant tree species from semi-arid savanna woodlands in Ethiopia. Trees 22:631-641.

Glenday, J., 2006. Carbon storage and emissions offset potential in an East African tropical rainforest. Forest Ecology and Management 235:72-83.

Hogg, E. H., 1997. Temporal scaling of moisture and the forestgrassland boundary in western Canada. Agricultural and Forest Meteorology 84:115-122.

IPCC, 2006. 2006 IPCC Guidelines for National Greenhouse Gas Inventories. Volume 4: Agriculture, Forestry and Other Land Use, edited by H. S. Eggleston, L. Buendia, T. Ngara, and K. Tanabe, IGES, Japan.

IPCC, 2007. Climate Change 2007: Impacts, Adaptation and Vulnerability. Contribution of working group II to the Fourth Assessment Report of the Intergovernmental Panel on Climate Change, edited by M. L. Parry, O. F. Canziani, J. P. Palutikof, P. J. van der Linden, and C. E. Hanson, Cambridge University Press, Cambridge, UK; 976 pp.

IPCC, 2008. Bilan 2007 des changements climatiques. Contribution des Groupes de travail I, II et III au Quatrieme Rapport d'Evaluation du Groupe d'Experts Intergouvernmental sur l'evolution du climat. Intergouvernmental Panel on Climate Change; 103 pp.

Jaetzold, R., and H. Schmidt, 1982. Farm management Handbook of Kenya. Volume 2: Natural Conditions and Farm Management Information. Ministry of Agriculture, Kenya; pp. 137-370.

Kaimowitz, D., 2008. The prospects for reduced emissions from deforestation and degradation (REDD) in Mesoamerica. International Forestry Review 10:485-495.

Krepkowski, J., A. Bräuning, A. Gebrekirstos, and S. Strobl, 2011. Cambial growth dynamics and climatic control of different tree life forms in tropical mountain forest in Ethiopia. Trees 25:59-70.

Kuyah, S., J. Dietz, C. Muthuri, R. Jamnadass, P. Mwangi, R. Coe, and H. Neufeldt, 2012. Allometric equations for estimating biomass in agricultural landscapes: I. Aboveground biomass. Agriculture, Ecoystems and Environment 158:216-224.

Legendre, P., and L. Legendre, 1998. Numerical Ecology. 2nd ed, Volume 20. Developments in Environmental Modeling. Elsevier Science B.V., Amsterdam, The Netherlands.

Lewis, S. L., G. Lopez-Gonzalez, B. Sonke, K. Affum-Baffoe, T. R. Baker, L. O. Ojo, O. L. Phillips, J. M. Reitsma, L.
White, J. A. Comiskey, M.-N. Djuikouo, C. E. N. Ewango, T. R. Feldpausch, A. C. Hamilton, M. Gloor, T. Hart, A. Hladik, J. Lloyd, J. C. Lovett, J.-R. Makana, Y. Malhi, F. M. Mbago, H. J. Ndangalasi, J. Peacock, K. S.-H. Peh, D. Sheil, T. Sunderland, M. D. Swaine, J. Taplin, D. Taylor, S. C. Thomas, R. Votere, and H. Woll, 2009. Increasing carbon storage in intact African tropical forests. Nature 457:1003-1007.

Luoga, E. J., S. A. O. Chamshama, and S. Iddi, 1994. Survival, growth, yield, and wood quality of a species and provenance trial of Cupressus lusitanica, Cupressus lindleyi and Cupressus benthamii at Hambalawei, Lushoto, Tanzania. Silvae Genetica 43:190-195.

Maingi, J. K., 2006. Growth rings in tree species from the Tana River floodplain. Journal of East African Natural History 95: 181-211.

Martin, D. M., and J. M. S. Moss, 1997. Age determination of Acacia tortilis (Forsk.) Hayne from northern Kenya. African Journal of Ecology 35:266-277.

Maundu, P., and B. Tengnäs, 2005. Useful Trees and Shrubs for Kenya. World Agroforestry Centre, Nairobi.

Mbow, C., S. Chhin, B. Sambou, and D. Skole, 2013. Potential of dendrochronology to assess annual rates of biomass productivity in savanna trees of West Africa. Dendrochronologia 31:41-51.

Mekonnen, K., T. Yohannes, G. Glatzel, and Y. Amha, 2006. Performance of eight tree species in the highland vertisols of central Ethiopia: Growth, foliage nutrient concentration, and effect on soil chemical properties. New Forests 32:285-298.

Metsaranta, J. M., and V. J. Lieffers, 2009. Using dendrochronology to obtain annual data for modeling stand development: A supplement to permanent sample plots. Forestry 82: $163-173$.

Mfundisi, K., 2005. Analysis of Carbon Pools and Human Impacts in the Yala Swamp (Western Kenya): A Landscape Approach. Ph.D. dissertation, University of Bonn, Germany.

Miller, J. T., and F. B. Knowles, 1990. Introduced Forest Trees in New Zealand: Recognition, Role, and Seed Source. The Cypresses, Cupressus spp., Chamaecyparis spp. Forest Research Institute Bulletin No. 124; 33 pp.

Nath, C. D., R. Pelissier, B. R. Ramesh, and C. Garcia, 2011. Promoting native trees in shade coffee plantations of southern India: Comparison of growth rates with the exotic Grevillea robusta. Agroforestry Systems 83:107-119.

Nicholas, I., 2007. Best Practice with Farm Forestry Timber Species, No. 1: Cypresses. NZFFA Electronic Handbook Series No. 1. www.nzffa.org,nz.

Rozendaal, D. M. A., and P. A. Zuidema, 2011. Dendroecology in the tropics: A review. Trees 25:3-16.

Schongart, J., B. Orthmann, K. J. Hennenberg, S. Porembski, and M. Worbes, 2006. Climate-growth relationships of tropical tree species in West Africa and their potential for climate reconstruction. Global Change Biology 12:1139-1150. Shorrocks, Bryan, 2007. The Biology of African Savannahs. New York.

Sousa, V. B., S. Cardoso, T. Quilho, and H. Pereira, 2012. Growth rate and ring width variability of teak, Tectona grandis (Verbenaceae) in an unmanaged forest in East Timor. Revista de Biologia Tropical 60:483-494. 
Stahle, D. W., 1999. Useful strategies for the development of tropical tree-ring chronologies. IAWA Journal 20:249-253.

Stahle, D. W., P. T. Mushove, M. K. Cleaveland, F. Roig, and G. A. Haynes, 1999. Management implications of annual growth rings in Pterocarpus angolensis from Zimbabwe. Forest Ecology and Management 124:217-229.

Tarhule, A., and M. Hughes, 2002. Tree-ring research in semiarid West Africa: need and potential. Tree-Ring Research 58: $31-46$.

Therrell, M. D., D. W. Stahle, M. M. Mukelabai, and H. H. Shugart, 2007. Age and radial growth dynamics of Pterocarpus angolensis in southern Africa. Forest Ecology and Management 244:24-31.

Trouet, V., J. Esper, and H. Beeckman, 2010. Climate/growth relationships of Brachystegia spiciformis from the miombo woodland in south central Africa. Dendrochronologia 28: 161-171.

Venables, W. N., and B. D. Ripley, 2002. Modern applied statistics with $S$, 4th ed. Springer, New York.

Verheyden, A., J. G. Kairo, H. Beeckman, and N. Koedam, 2004. Growth rings, growth ring formation and age determination in the mangrove Rhizophora mucronata. Annals of Botany 94:59-66.

Verheyden, A., F. De Ridder, N. Schmitz, H. Beeckman, and N. Koedam, 2005. High-resolution time series of vessel density in Kenyan mangrove trees reveal a link with climate. New Phytologist 167:425-435.

Watt, M., D. Palmer, H. Dungey, and M. Kimberly, 2009. Predicting the spatial distribution of Cupressus lusitanica productivity in New Zealand. Forest Ecology and Management 258:217-223.

Wils, T. H. G., U. G. W. Sass-Klaassen, Z. Eshetu, A. Brauning, A. Gebrekirstos, C. Couralet, I. Robertson, R. Touchan, M. Koprowski, D. Conway, K. R. Briffa, and H. Beeckman, 2011. Dendrochronology in the dry tropics: The Ethiopian case. Trees 25:345-354.

Worbes, M., 1995. How to meaure growth dynamics in tropical trees. A review. IAWA Journal 16:337-351.

, 2002. One hundred years of tree-ring research in the tropics - A brief history and an outlook to future challenges. Dendrochronologia 20:217-231.

Worbes, M., and W. J. Junk, 1999. How old are tropical trees? The persistence of a myth. IAWA Journal 20:255-260.

Worbes, M., R. Staschel, A. Roloff, and W. J. Junk, 2003. Tree ring analysis reveals age structure, dynamics and wood production of a natural forest stand in Cameroon. Forest Ecology and Management 173:105-123.

Yamaguchi, D. K., 1991. A simple method for cross dating increment cores for living trees. Canadian Journal Forest Research 21:414-416.

Zomer, R. J., A. Trabucco, R. Coe, and F. Place, 2009. Trees on Farm: Analysis of Global Extent and Geographical Patterns of Agroforestry. World Agroforestry Centre Working Paper no. 89. World Agroforestry Centre, Nairobi.

Received 29 November 2012; accepted 31 March 2014. 